\title{
Catechin hydrate suppresses MCF-7 proliferation through TP53/Caspase-mediated apoptosis
}

\author{
Ali A Alshatwi
}

\begin{abstract}
Catechin hydrate $(\mathrm{CH})$, a strong antioxidant that scavenges radicals, is a phenolic compound that is extracted from plants and is present in natural food and drinks, such as green tea and red wine. CH possesses anticancer potential. The mechanism of action of many anticancer drugs is based on their ability to induce apoptosis. In this study, I sought to characterize the downstream apoptotic genes targeted by $\mathrm{CH}$ in MCF-7 human breast cancer cells. $\mathrm{CH}$ effectively kills MCF-7 cells through induction of apoptosis. Apoptosis was confirmed by terminal deoxynucleotidyl transferase-mediated dUTP nick end labeling (TUNEL) and real-time PCR assays. Cells were exposed to $150 \mu \mathrm{g} / \mathrm{ml}$ $\mathrm{CH}$ and $300 \mu \mathrm{g} / \mathrm{mL} \mathrm{CH}$ for 24 hours, which resulted in $40.7 \%$ and $41.16 \%$ apoptotic cells, respectively. Moreover, a 48-hour exposure to $150 \mu \mathrm{g} / \mathrm{ml} \mathrm{CH}$ and $300 \mu \mathrm{g} / \mathrm{ml} \mathrm{CH}$ resulted in $43.73 \%$ and 52.95\% apoptotic cells, respectively. Interestingly, after 72 hours of exposure to both concentrations of $\mathrm{CH}$, almost 100\% of cells lost their integrity. These results were further confirmed by the increased expression of caspase-3,-8, and -9 and TP53 in a time-dependent and dose-dependent manner, as determined by real-time quantitative PCR. In summary, the induction of apoptosis by $\mathrm{CH}$ is affected by its ability to increase the expression of pro-apoptotic genes such as caspase-3, -8, and -9 and TP53.
\end{abstract}

\section{Introduction}

Catechin compounds including (-)- epigallocatechin-3gallate (EGCG), (-)- epigallocatechin (EGC), epicatechin3-gallate (ECG) and (p)catechin [1] have been shown to exhibit cytostatic properties in many tumor models $[2,3]$. In addition, the growth of new blood vessels required for tumor growth has been prevented by green tea [4]. In Asian countries, a number of epidemiological observations have suggested that the low incidence of some cancers is due to the consumption of green tea $[2,3]$. Moreover, epidemiological observations have suggested that the consumption of green tea inhibits growth of many tumor types [5,6].

Breast cancer is the most common cancer and is the leading cause of death for women worldwide [7]. Several epidemiological observations have suggested that increased consumption of green tea is related to improved prognosis of human breast cancer [2] and that the low risk of breast cancer is associated with the intake of green tea in Asian-Americans [8,9].

\section{Correspondence: alialshatwi@gmail.com}

Molecular Cancer Biology Research Lab (MCBRL), Dept. of Food Science and Nutrition, College of Agriculture and Food Sciences, King Saud University, Saudi Arabia
The modulation of signal transduction pathways, inhibition of cell proliferation, induction of apoptosis, inhibition of tumor invasion and inhibition of angiogenesis are mechanisms that have been established as inhibiting carcinogenesis $[10,11]$. These potentially beneficial effects of green tea are attributed to catechin compounds, particularly EGCG, which is the most abundant and extensively studied catechin compound of green tea $[12,13]$.

The overall medicinal effects of green tea observed thus far, are focused on combined activities of several compounds in green tea rather than that of a single compound. In addition, most studies have investigated the different synergistic bioactivities of all compounds present in tea extracts or have been focused mainly on the role of EGCG. Therefore, the present study was designed to elucidate the role of the anticancer activity of single compound i.e. $\mathrm{CH}$ (Figure 1) at the molecular level.

\section{Materials and methods \\ Catechin Hydrate-A compound of Catechins}

Catechin is a polyphenolic flavonoid which has been isolated from a variety of natural sources including tea 


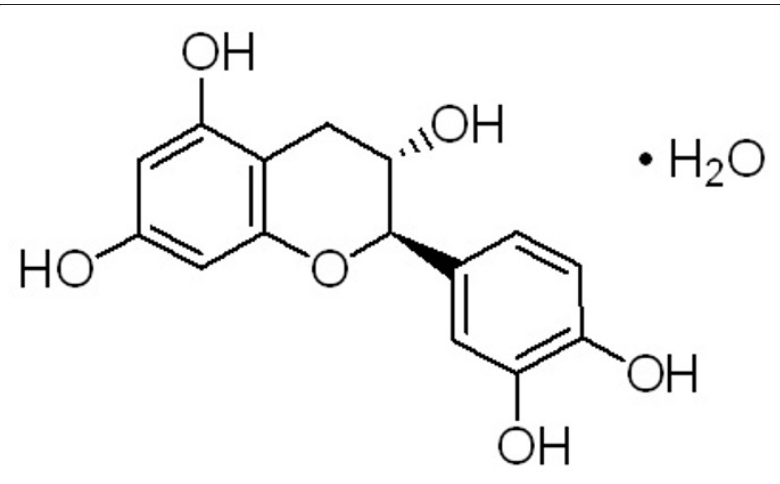

Figure 1 Molecular structure of catechin hydrate.

leaves, grape seeds, and the wood and bark of trees such as acacia and mahogany. Catechin is a more potent antioxidant than ascorbate or $\alpha$-tocopherol in certain in vitro assays of lipid peroxidation. Catechin inhibits the free radical-induced oxidation of isolated LDL by AAPH [14]. Catechins and other related procyanidin compounds have antitumor activity when tested in a two-stage mouse epidermal carcinoma model employing topical application. Following is the structure of (+)-Catechin hydrate.

\section{Preparations of $\mathrm{CH}$}

$100 \mathrm{mg} \mathrm{CH}$ was dissolved in $10 \mathrm{~mL}$ DMEM medium (10\% FCS) to obtain stock solution and was further diluted in medium to obtain desired concentrations.

\section{Maintenance of MCF-7 Cells}

The MCF-7 breast cancer cell line was a kind gift from Dr. M. A. Akbarshah at the Mahatma Gandhi-Doerenkamp Center (MGDC) for Alternatives to Use of Animals in Life Science Education, Bharathidasan University, India. The cell line was maintained and propagated in 90\% Dulbecco's Modified Eagle's Medium (DMEM) containing $10 \%$ fetal bovine serum (FBS) and 1\% penicillin/ streptomycin. Cells were cultured as adherent monolayers (i.e., cultured at $\sim 70 \%$ to $80 \%$ confluence) and maintained at $37^{\circ} \mathrm{C}$ in a humidified atmosphere of $5 \%$ $\mathrm{CO} 2$. Cells were harvested after being subjected to brief trypsinization. All chemicals used were of research grade.

\section{Viability of Cells}

Cell viability was assayed using a trypan blue exclusion test as explained earlier with slight modifications [15].

\section{Toxicity and Cell Proliferation Assays}

The Cell Titer Blue ${ }^{\oplus}$ viability assay (Promega Madison, WI) was performed to assess the toxicity of different concentrations of $\mathrm{CH}$ on MCF-7 cells. The assay was performed according to the manufacturer's instructions.
Briefly, MCF-7 cells $\left(2 \times 10^{4}\right.$ cells/well $)$ were plated in 96-well plates and treated with $0 \mu \mathrm{g} / \mathrm{mL} \mathrm{CH}$ and $160 \mu \mathrm{g} / \mathrm{mL} \mathrm{CH}$ for 24 hours. Then, $40 \mu \mathrm{L}$ of the Cell Titer Blue solution was directly added to the wells and incubated at $37^{\circ} \mathrm{C}$ for 6 hours. The fluorescence was recorded with a $560 \mathrm{~nm} / 590 \mathrm{~nm}$ (excitation/emission) filter set using a Bio-Tek microplate fluorescence reader $\left(\mathrm{FLx} 800^{\mathrm{TM}}\right)$, and the $\mathrm{IC}_{50}$ was calculated. Quadruplet samples were run for each concentration of $\mathrm{CH}$ in three independent experiments.

\section{$\mathrm{CH}$ Treatment for a concentration- and Time-Dependent Study}

For a concentration- and time-dependent study, two sets of $\mathrm{CH}$ concentrations $(50 \mu \mathrm{g} / \mathrm{mL}$ and $150 \mu \mathrm{g} / \mathrm{mL}$; $300 \mu \mathrm{g} / \mathrm{mL}$ and $600 \mu \mathrm{g} / \mathrm{mL}$ ) were considered for treatment of MCF-7 cells for 24 hours. I found that $50 \mu \mathrm{g} /$ $\mathrm{mL} \mathrm{CH}$ did not show any significant induction of apoptosis whereas $600 \mu \mathrm{g} / \mathrm{mL} \mathrm{CH}$ completely killed the cells. Hence, $150 \mu \mathrm{g} / \mathrm{mL}$ and $300 \mu \mathrm{g} / \mathrm{mL}$ concentrations of $\mathrm{CH}$ were used for further studies.

MCF-7 cells were treated with either $150 \mu \mathrm{g} / \mathrm{mL}$ or $300 \mu \mathrm{g} / \mathrm{mL} \mathrm{CH}$ for 24, 48 and 72 hours for the terminal deoxynucleotidyl transferase-mediated dUTP nick end labeling (TUNEL) assay. The cells were incubated with the same CHconcentrations for 24 and 48 hours for real-time quantitative PCR analysis.

\section{TUNEL Assay}

The DeadEnd ${ }^{\oplus}$ TUNEL assay kit (Promega, Madison, WI) was used for studying apoptosis in a time- and dose-dependent manner. The manufacturer's instructions were followed with slight modifications. Briefly, MCF-7 cells $\left(1.5 \times 10^{6}\right.$ cells/well $)$ were cultured in 6-well plates to study apoptosis in adherent cells. Cells were treated with $150 \mu \mathrm{g} / \mathrm{mL}$ and $300 \mu \mathrm{g} / \mathrm{mL} \mathrm{CH}$ for 24, 48 and 72 hours. After the incubation period, the culture medium was aspirated off, and the cell layers were trypsinized. The trypsinized cells were reattached on $0.01 \%$ polylysine-coated slides, fixed with $4 \%$ methanol-free formaldehyde solution, and stained according to the DeadEnd fluorometric TUNEL system protocol [16]. The stained cells were observed using a Carl-Zeiss (Axiovert) epifluorescence microscope using a triple band-pass filter. To determine the percentage of cells demonstrating apoptosis, 1000 cells were counted in each experiment [17].

\section{Real-time quantitative PCR analysis}

The expression of apoptotic genes was analyzed by reverse transcription-PCR (RT-PCR; Applied Biosystems 7500 Fast, Foster City, CA) using a real-time SYBR Green/ROX gene expression assay kit (QIAgen). The cDNA was directly prepared from cultured cells using a 
Fastlane ${ }^{\oplus}$ Cell cDNA kit (QIAGEN, Germany), and the mRNA levels of Caspase 3, Caspase 8, Caspase 9 and $t p 53$ as well as the reference gene, GAPDH, were assayed using gene-specific SYBR Green-based QuantiTect $^{\circledast}$ Primer assays (QIAGEN, Germany). Quantitative real-time RT-PCR was performed in a reaction volume of $25 \mu \mathrm{L}$ according to the manufacturer's instructions. Briefly, $12.5 \mu \mathrm{L}$ of master mix, $2.5 \mu \mathrm{L}$ of primer assay $(10 \times)$ and $10 \mu \mathrm{L}$ of template cDNA $(100 \mu \mathrm{g})$ were added to each well. After a brief centrifugation, the PCR plate was subjected to 35 cycles of the following conditions: (i) PCR activation at $95^{\circ} \mathrm{C}$ for 5 minutes, (ii) denaturation at $95^{\circ} \mathrm{C}$ for 5 seconds and (iii) annealing/extension at $60^{\circ} \mathrm{C}$ for 10 seconds. All samples and controls were run in triplicates on an ABI 7500 Fast Real-time PCR system. The quantitative RT-PCR data was analyzed by a comparative threshold $(\mathrm{Ct})$ method, and the fold inductions of samples were compared with the untreated samples. GAPDH was used as an internal reference gene to normalize the expression of the apoptotic genes. The $\mathrm{Ct}$ cycle was used to determine the expression level in control cells and MCF-7 cells treated with $\mathrm{CH}$ for 24 and $48 \mathrm{~h}$. The gene expression level was then calculated as described earlier [18]. The results were expressed as the ratio of reference gene to target gene by using the following formula: $\Delta \mathrm{Ct}=\mathrm{Ct}$ (apoptotic genes) - Ct (GAPDH). To determine the relative expression levels, the following formula was used: $\Delta \Delta \mathrm{Ct}$ $=\Delta \mathrm{Ct}$ (Treated) $-\Delta \mathrm{Ct}$ (Control). Thus, the expression levels were expressed as $\mathrm{n}$-fold differences relative to the calibrator. The value was used to plot the expression of apoptotic genes using the expression of $2^{-\Delta \Delta C t}$.

\section{Results}

Effect of CH on MCF-7 breast cancer cell proliferation and apoptosis

To explore the anticancer effect of $\mathrm{CH}$ on MCF-7 human breast cancer cells, several in vitro experiments were conducted.

\section{Viability assay}

The viability of cells was greater than $95 \%$.

\section{Determination of $\mathrm{CH}$ toxicity on MCF-7 cells}

The cytotoxic effect of $0 \mu \mathrm{g} / \mathrm{mL} \mathrm{CH}$ and $160 \mu \mathrm{g} / \mathrm{mL} \mathrm{CH}$ on MCF-7 cells was examined using the Cell Titer Blue ${ }^{\oplus}$ viability assay (Promega Madison, WI). A dose-dependent reduction in color was observed after 24 hours of treatment with $\mathrm{CH}$, and $54.76 \%$ of the cells were dead at the highest concentration of $\mathrm{CH}$ tested $(160 \mu \mathrm{g} / \mathrm{mL})$ whereas the $\mathrm{IC}_{50}$ of $\mathrm{CH}$ was achieved at $127.62 \mu \mathrm{g} / \mathrm{mL}$ $\mathrm{CH}$ (Figure 2).

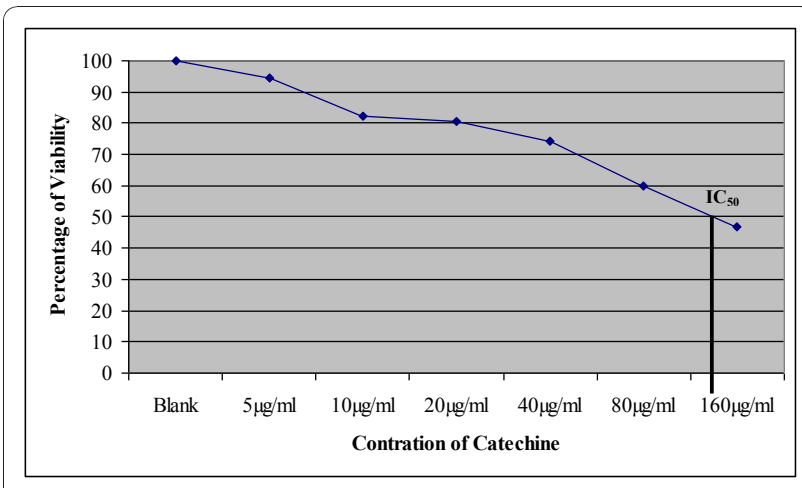

Figure 2 Determination of $\mathrm{IC}_{50}$ of catechin against the MCF-7 breast cancer cell line.

\section{Quantification of apoptosis by a TUNEL assay}

To determine whether the inhibition of cell proliferation by $\mathrm{CH}$ was due to the induction of apoptosis, a TUNEL assay was used. Figures 3, 4, 5 and 6 summarize the effect of $\mathrm{CH}$ on MCF-7 cells. A dose- and time-dependent increase in the induction of apoptosis was observed when MCF-7 cells were treated with $\mathrm{CH}$. When compared to the control cells at 24 hours, 40.7 and $41.16 \%$ of the cells treated with $150 \mu \mathrm{g} / \mathrm{mL}$ and $300 \mu \mathrm{g} / \mathrm{mL} \mathrm{CH}$, respectively, underwent apoptosis. Similarly, 43.73 and $52.95 \%$ of the cells treated with $150 \mu \mathrm{g} / \mathrm{mL}$ and $300 \mu \mathrm{g} /$ $\mathrm{mL} \mathrm{CH}$, respectively, for 48 hours underwent apoptosis. Interestingly, after 72 hours of exposure to $\mathrm{CH}$, almost $100 \%$ of the cells in both concentrations had lost their integrity (Figure 6).

\section{Quantification of mRNA levels of apoptotic-related genes}

To investigate the molecular mechanism of $\mathrm{CH}$-induced apoptosis in MCF-7 cells, the expression levels of several

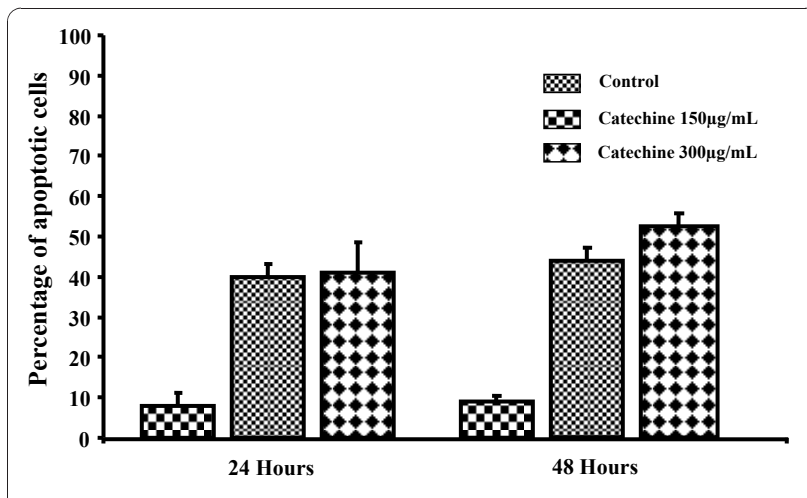

Figure 3 Percentage of apoptotic cells in 24 hours and 48 hours incubation in blank control and treatments with catechin hydrate $(150 \mu \mathrm{g} / \mathrm{mL}$ and $300 \mu \mathrm{g} / \mathrm{mL})$. 


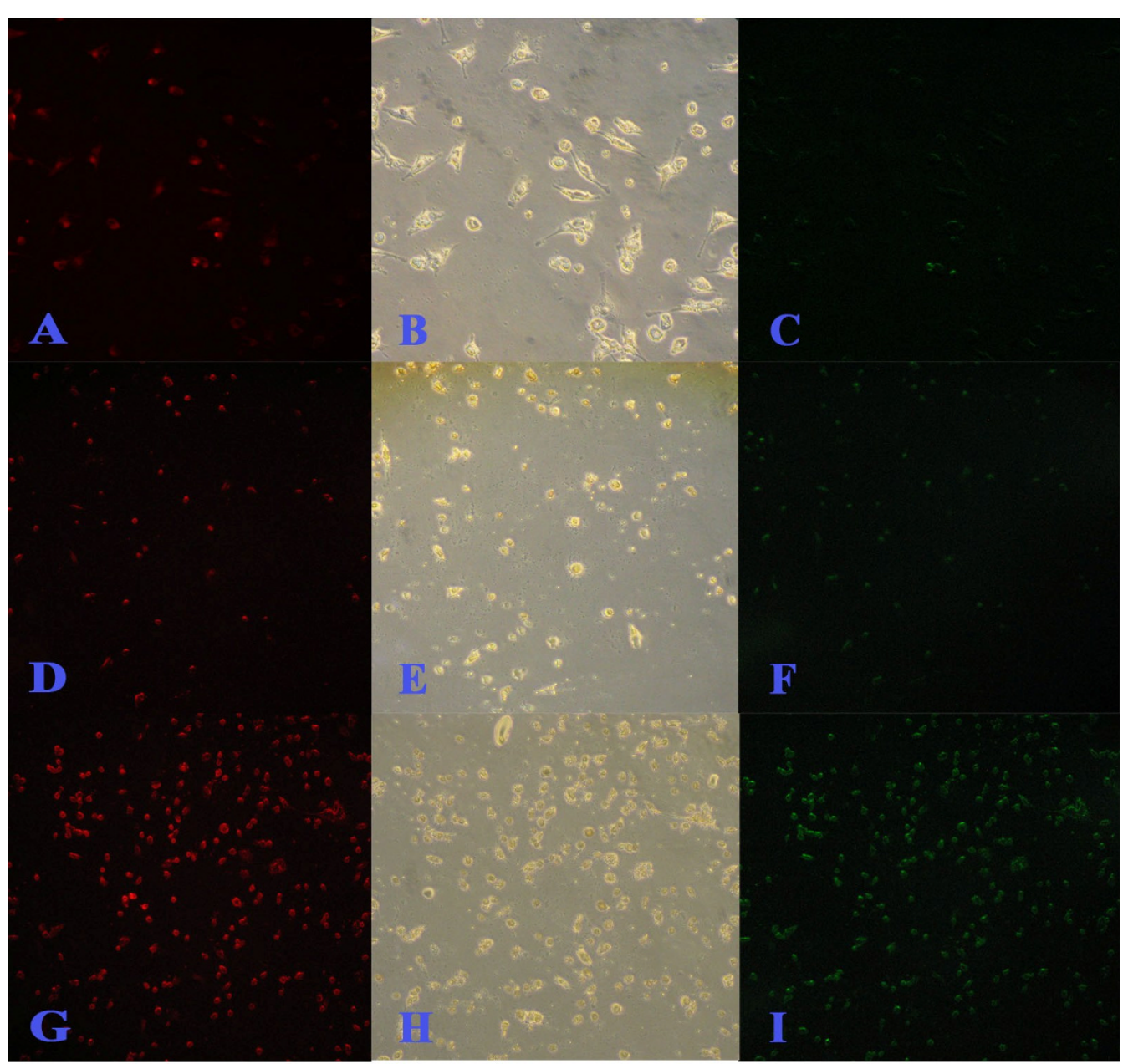

Figure 4 TUNEL assay (microscopic) after 24 hours incubation of MCF-7 against catechine treatment. A, B and C are untreated control; $\mathrm{D}, \mathrm{E}$ and $\mathrm{F}$ treated with $150 \mu \mathrm{g} / \mathrm{mL}$ of catechine; G, H and I treated with $300 \mu \mathrm{g} / \mathrm{mL}$ of catechine. Red fluorescence is due to Propedium lodide staining and observed under green filter while green fluorescence is due to FITC staining and observed under blue filter. Bright field image (B, E and H) central row. Observations done at 200x magnification.

apoptosis-related genes were examined. The relative quantification of Caspase-3, -8 , and -9 and Tp53 mRNA expression levels was performed by SYBR Green-based quantitative real-time PCR (RT-PCR) using a 7500 Fast Real Time System (Applied Biosystems).

Figures 7 to 10 summarize the gene expression changes of Caspase- $3,-8$, and -9 and $p 53$. $\mathrm{CH}$ increased the transcripts of Caspase 3, -8 , and -9 , and $p 53$ by several fold. The expression levels of these genes in MCF-7 cells treated with $150 \mu \mathrm{g} / \mathrm{ml} \mathrm{CH}$ for $24 \mathrm{~h}$ increased by $5.81,1.42,3.29$, and 2.68 fold, respectively, as compared to the levels in untreated control cells (Figure 7). Similarly, the expression levels of Caspase- $3,-8$, and -9 and p53 in MCF-7 cells treated with $300 \mu \mathrm{g} / \mathrm{ml} \mathrm{CH}$ for $24 \mathrm{~h}$ increased by $7.09,3.8,478$, and 4.82 fold, respectively, as compared to levels in untreated control cells (Figure 8). In a time-dependent manner, the expression levels of the apoptotis-related genes in MCF-7 cells treated with 150 or $300 \mu \mathrm{g} / \mathrm{ml} \mathrm{CH}$ for $48 \mathrm{~h}$ increased when compared to the levels in untreated control cells (Figure 9 and 10). However, the expression levels of Caspase-3, -8 , and -9 and $p 53$ in MCF-7 cells treated with $300 \mu \mathrm{g} /$ $\mathrm{ml} \mathrm{CH}$ for $48 \mathrm{~h}$ markedly increased-40.52, 8.72, 20.26 and 10 fold-as compared to control untreated cells (Figure 10). Together, these data suggest that these caspases and p53 were induced by $\mathrm{CH}$ in a dose- and timedependent manner.

\section{Discussion}

The mechanism of action of many anticancer drugs is based on their ability to induce apoptosis $[19,20]$. There are many mechanisms through which apoptosis can be enhanced in cells. Agents suppressing the proliferation of malignant cells by enhancing apoptosis may constitute a 


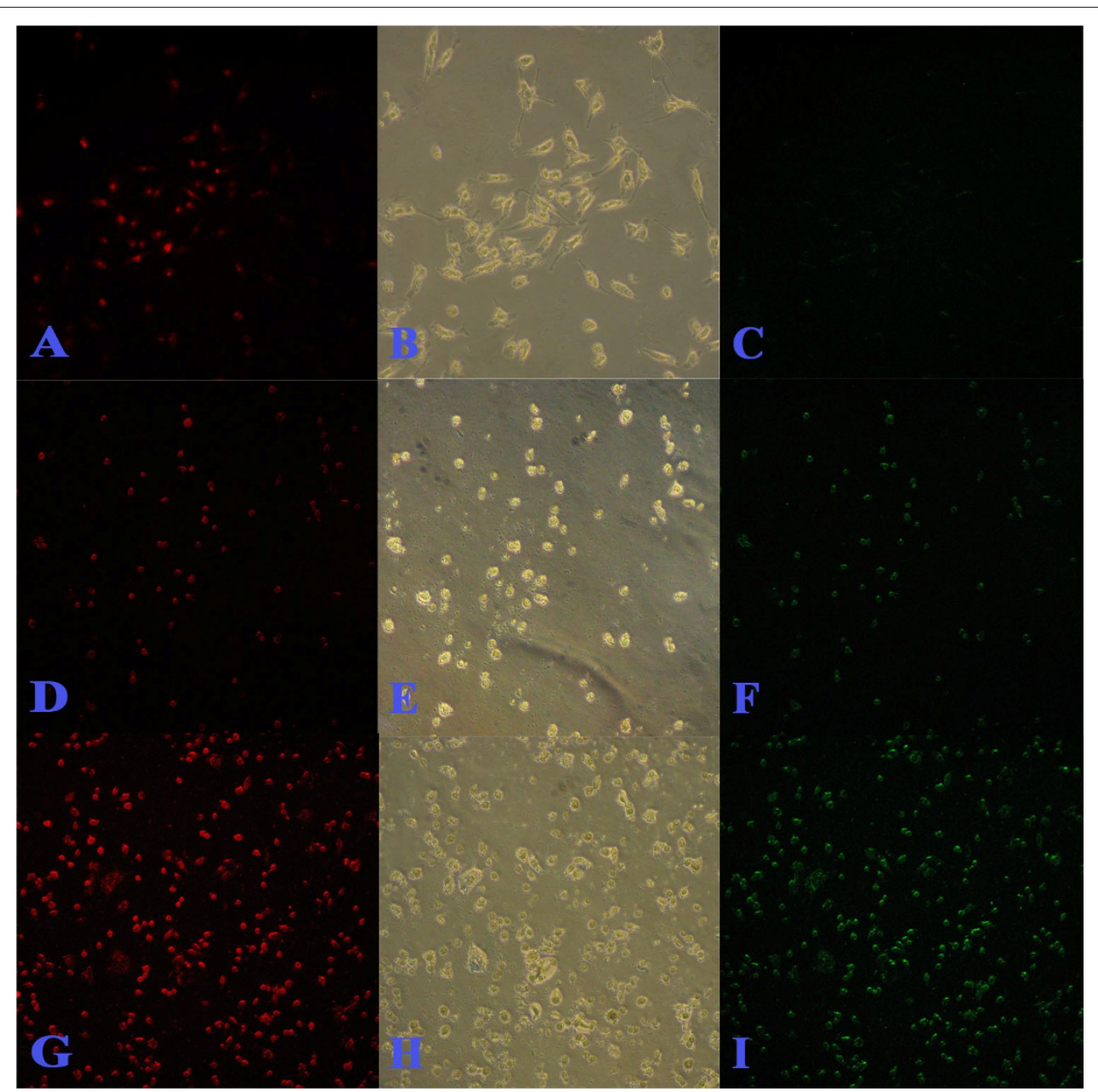

Figure 5 TUNEL assay (microscopic) after 48 hours incubation of MCF-7 against catechine treatment. A, B and C are untreated control; D, E and F treated with $150 \mu \mathrm{g} / \mathrm{mL}$ of catechine; $\mathrm{G}, \mathrm{H}$ and I treated with $300 \mu \mathrm{g} / \mathrm{mL}$ of catechine. Red fluorescence is due to Propedium lodide staining and observed under green filter while green fluorescence is due to FITC staining and observed under blue filter. Bright field image (B, E and H) central row. Observations done at 200x magnification.

useful mechanistic approach to both cancer chemoprevention and chemotherapy. However, unfavorable side effects and resistance of many of the anticancer agents that have been developed are serious problems [21]. Thus, there is a growing interest in the use of plantbased compounds to develop safe and more effective therapeutic agents for cancer treatment [22]. Because the side effects of green tea are modest and well tolerated [23], increasing attention is being given to the application of tea catechins for cancer prevention and treatment. EGCG conjugated with capric acid has been shown to be the catechin that most potently induces apoptosis in U937 cells. C10 has been shown to enhance apoptosis in human colon cancer (HCT116) cells [24]. Catechin compounds have been shown to exhibit cytostatic properties in many tumor models [2,3]. Babich et al. (2005) found that catechin and epicatechin (EC) are less toxic than other catechin compounds, including ECG, CG, EGCG and EGC, in HSC-2 carcinoma cells and HGF-2 fibroblasts [25]. Hence, I was interested in identifying whether apoptosis was the mode of death for cancer cells treated with $\mathrm{CH}$ (the least toxic form). To do so, I sought to determine the role of $\mathrm{CH}$ in inhibiting cell growth and modulating the expression of caspases- $3,-8$, and -9 and $\mathrm{p} 53$.

The data presented in this paper demonstrate a timeand dose-dependent inhibition by $\mathrm{CH}$ of MCF-7 human breast cancer cell proliferation. There are many mechanisms through which apoptosis can be induced in cells. The sensitivity of cells to any of these stimuli may vary depending on factors such as the expression of pro- and anti-apoptotic proteins. The mitochondrial apoptotic pathways and death receptor pathways are the two major pathways that have been characterized in mammalian 


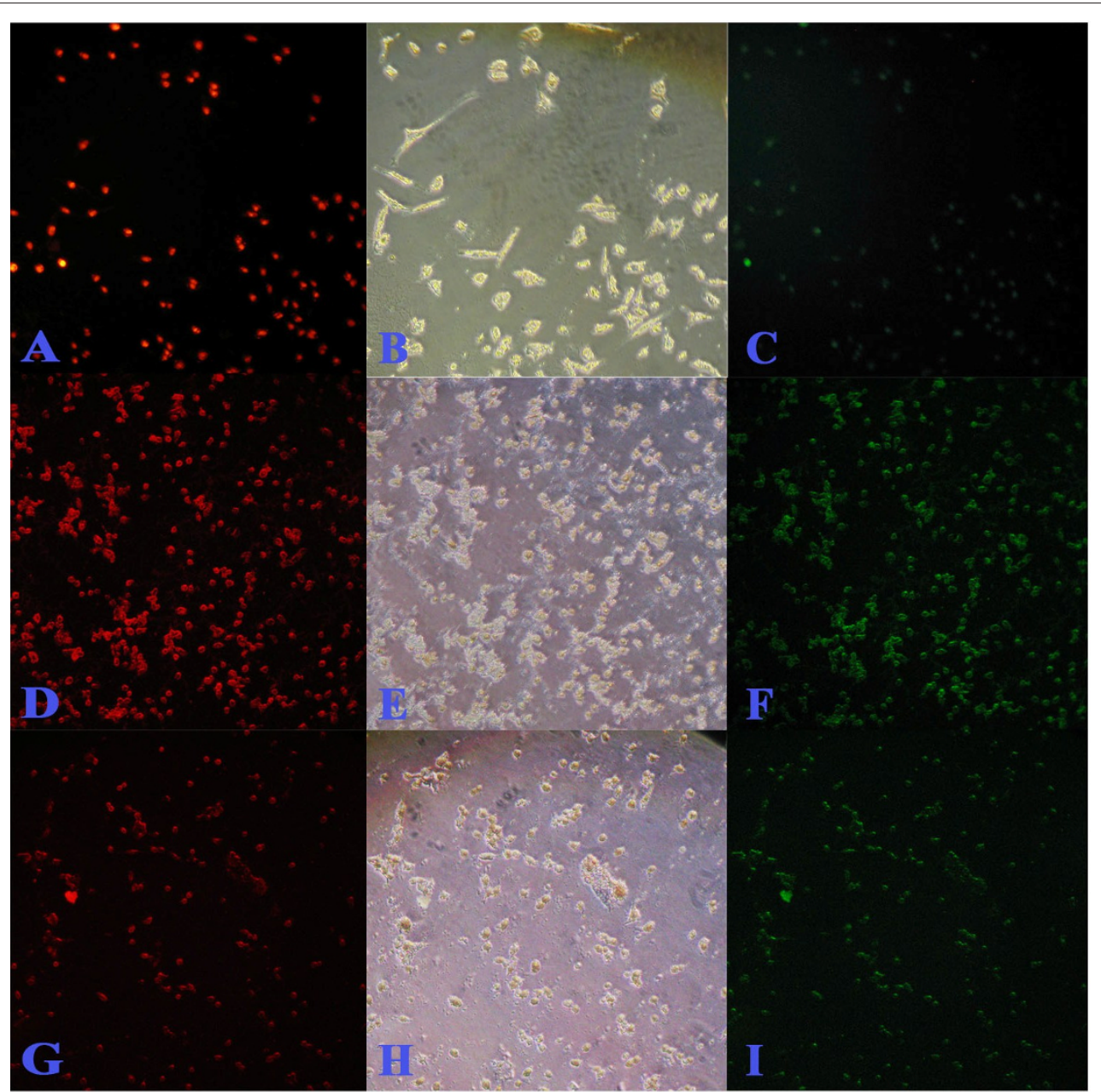

Figure 6 TUNEL assay (microscopic) after 72 hours incubation of MCF-7 against catechine treatment. A, B and C are untreated control; $\mathrm{D}, \mathrm{E}$ and F treated with $150 \mu \mathrm{g} / \mathrm{mL}$ of catechine; $\mathrm{G}, \mathrm{H}$ and I treated with $300 \mu \mathrm{g} / \mathrm{mL}$ of catechine. Red fluorescence is due to Propedium lodide staining and observed under green filter while green fluorescence is due to FITC staining and observed under blue filter. Bright field image (B, E and H) central row. Observations done at 200x magnification.

cells. The mitochondria have a central role in regulating the caspase cascade and apoptosis [26]. Caspases have a central role in the apoptotic process in that they trigger a cascade of apoptotic pathways [27]. The release of cytochrome -c from mitochondria leads to the activation of procaspase-9 and then caspase-3 [26]. The activation of caspase-3 is an important downstream step in the apoptotic pathway [28]. In addition, the effector caspase, caspase- 3 , and the initiator caspases, caspase- 8 and -9 , are the main executors of apoptosis [29]. Caspase- 8 is in the death receptor pathway whereas caspase- 9 is in the mitochondrial pathway, and both pathways share caspase- 3 [30]. Treatment with EGCG conjugated with capric acid increases the formation of reactive oxygen species (ROS), loss of mitochondrial membrane potential (MMP), release of cytochrome c, activation of caspase- 9 and activation of caspase-3. In addition, EGCG conjugated with capric acid also activates the extrinsic pathway as demonstrated by the time-dependent increase in Fas expression and caspase- 8 activity [24]. Two distinct downstream pathways have been identified for activation of apoptosis after caspase- 8 is activated. In one pathway, caspase- 8 directly processes downstream effector caspase- $3,-6$, and -7 . In an alternative pathway, caspase- 8 activates crosstalk between the death receptor pathway and the mitochondrial pathway by the cleavage of Bid to Bid, a pro-apoptotic member of the Bcl2 family. The activation of caspase-8 has a central role in Fas-mediated apoptosis. Moreover, the cleavage of Bid has been shown to be associated with caspase- 8 activation [31]. Taken together, the data presented in this study suggest that catechininduced apoptosis is mediated by the death receptor and mitochondrial apoptotic pathways as demonstrated by increased expression levels of caspase-3, -8 and -9 after 


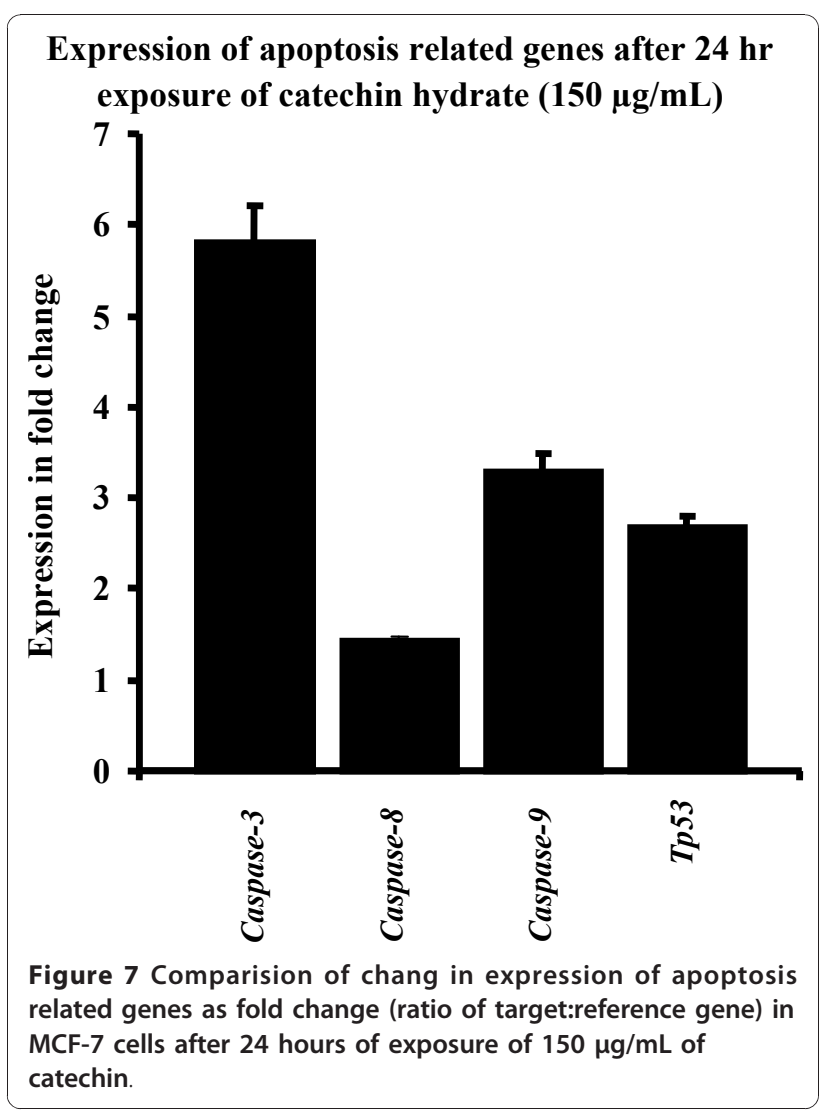

Expression of apoptosis related genes after $24 \mathrm{hr}$ exposure of catechin hydrate $(300 \mu \mathrm{g} / \mathrm{mL})$

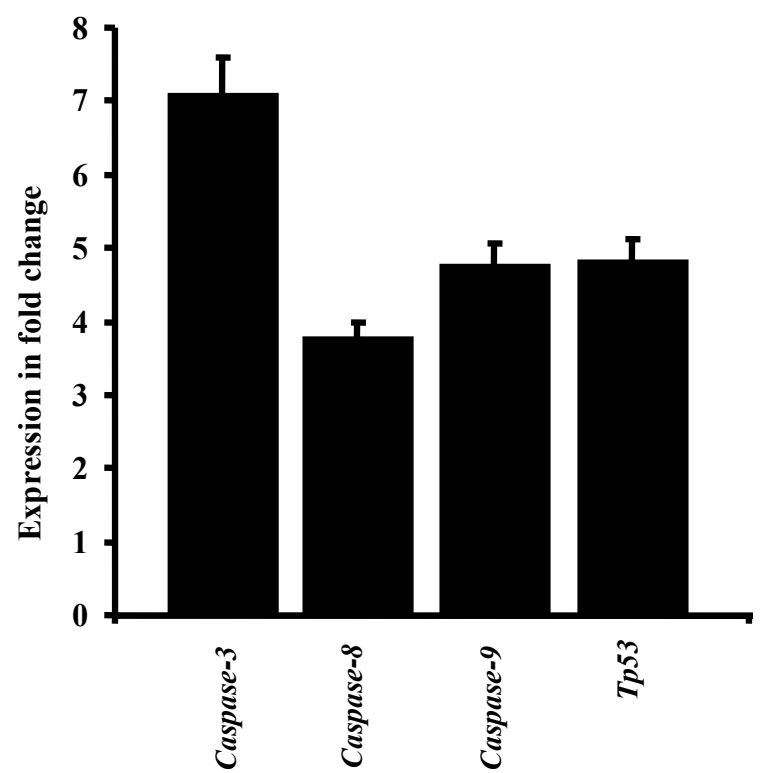

Figure 8 Comparision of chang in expression of apoptosis related genes as fold change (ratio of target:reference gene) in MCF-7 cells after 24 hours of exposure of $300 \mu \mathrm{g} / \mathrm{mL}$ of catechin.

\section{Expression of apoptosis related genes after $48 \mathrm{hr}$ exposure of catechin hydrate $(150 \mu \mathrm{g} / \mathrm{mL})$}

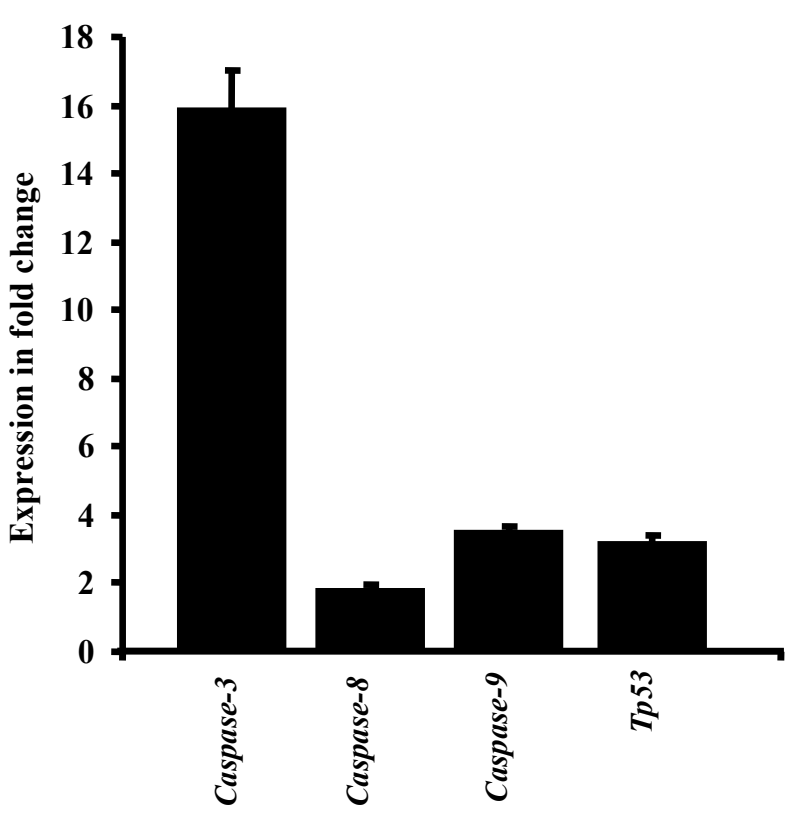

Figure 9 Comparision of chang in expression of apoptosis related genes as fold change (ratio of target:reference gene) in MCF-7 cells after 48 hours of exposure of $150 \mu \mathrm{g} / \mathrm{mL}$ of catechin

Expression of apoptosis related genes after $48 \mathrm{hr}$ exposure of catechin hydrate $(300 \mu \mathrm{g} / \mathrm{mL})$

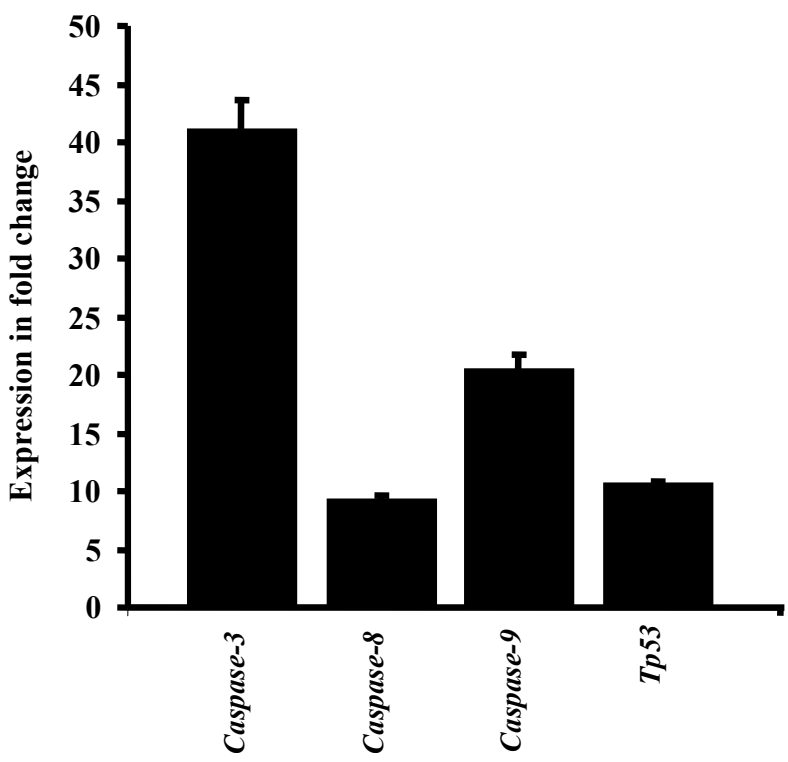

Figure 10 Comparision of chang in expression of apoptosis related genes as fold change (ratio of target:reference gene) in MCF-7 cells after 48 hours of exposure of $300 \mu \mathrm{g} / \mathrm{mL}$ of catechin. 
$\mathrm{CH}$ treatment. In addition, this study suggests that catechin activates the extrinsic death pathway as demonstrated by increased expression levels of caspase- 8 .

p53, the most commonly mutated gene associated with cancer [32], helps to regulate the cell cycle and has a key role in ensuring that damaged cells are destroyed by apoptosis. The data presented in this study indicate that the expression levels of p53 and caspase- $3,-8$ and -9 were markedly increased after $\mathrm{CH}$ treatment in a concentration-dependent manner. These data suggest that catechin induced apoptosis by regulating pro-apoptotic genes.

The possibility that p53-mediated apoptosis may be associated with the activation of caspase- $3,-8$ and -9 is suggested by the ability of p53 to activate both the extrinsic and intrinsic apoptotic pathways [30,33,34]. p53 enhances cancer cell apoptosis, and it prevents cell replication by stopping the cell cycle at G1 or interphase [35]. By inducing the release of mitochondrial cytochrome c, p53 might be able to activate effector caspases including caspase- 3 . Caspase- $3,-8$, and -9 may be the apoptotic effector machinery engaged by p53 to mediate teratogen-induced apoptotic pathways [36].

\section{Conclusion}

In conclusion, to our knowledge, the results presented in this study show for the first time that $\mathrm{CH}$ exhibits anticancer effects by blocking the proliferation of MCF7 cells and inducing apoptosis in part by modulating expression levels of caspase- $3,-8$, and -9 and p53. The induction of apoptosis by $\mathrm{CH}$ is affected by its ability to regulate the expression of pro-apoptotic genes such as caspase- $3,-8$, and -9 and $\mathrm{p} 53$. Taken together, it is most likely that $\mathrm{CH}$ induced, at least in part, p53 and caspase-mediated apoptosis in MCF-7 cells. Therefore, the present study demonstrates that $\mathrm{CH}$ significantly inhibits the growth of MCF-7 human breast cancer cells in vitro, and it provides the underlying mechanism for the anticancer activity. $\mathrm{CH}$ suppressed the growth of breast cancer cells without significant toxicity, making it a promising chemotherapeutic agent for breast cancer treatment; this is likely to be confirmed by further investigation.

\footnotetext{
Acknowledgements

I am indebted to Tarique N. Hasan and Gowhar Shafi for their technical help. I would like to acknowledge Research Centre, Deanship of Research, College of Food and Agricultural Sciences, King Saud University, Riyadh Saudi Arabia for their financial support. I also thank to the University Vice Presidency of Postgraduate Studies and Research, King Saud University, Saudi Arabia for their timely help.
}

\section{Competing interests}

The author declares that they have no competing interests.

Received: 6 September 2010 Accepted: 17 December 2010 Published: 17 December 2010
References

1. Graham HN: Green tea composition, consumption, and polyphenol chemistry. Preventive Medicine 1992, 21:334-350.

2. Nakachi K, Suemasu K, Suga K, Takeo T, Imai K, Higashi Y: Influence of drinking green tea on breast cancer malignancy among Japanese patients. Japanese Journal of Cancer Research 1998, 89:254-261.

3. Zhang Y, Han G, Fanm B, Zhou Y, Zhou X, Wei L, Zhang J: Green tea (-)-epigallocatechin-3-gallate down-regulates VASP expression andinhibits breast cancer cell migration and invasion by attenuating Rac1 activity. European Journal of Pharmacology 2009, 606:172-179.

4. Cao R: Angiogenesis inhibited by drinking tea. Nature 1999, 398:381.

5. Katiyar SK, Elmets CA: Green tea polyphenolic antioxidants and skin photoprotection (Review). International Journal of Oncology 2001, 18:1307-1313.

6. Ahmad N, Mukhtar H: Green tea polyphenols and cancer: biologic mechanisms and practical implications. Nutrition Reviews 1999, 57:78-83.

7. Lu X, Kang Y: Organotropism of breast cancer metastasis. Jourmal of Mammary Gland Biology and Neoplasia 2007, 12:153-162.

8. Wu AH, Tseng CC, Van Den B, Yu MC: Tea intake, COMT genotype, and breast cancer in Asian-American women. Cancer Research 2003, 63:7526-7529.

9. Wu AH, Yu MC, Tseng CC, Hankin J, Pike MC: Green tea and risk of breast cancer in Asian Americans. International Journal of Cancer 2003, 106:574-579.

10. Carlson JR, Bauer BA, Vincent A, Limburg PJ, Wilson T: Reading the tea leaves: anticarcinogenic properties of (-)-epigallocatechin-3-gallate. Mayo Clinic Proceeding 2007, 82:725-732.

11. Shankar S, Ganapathy G, Shrivastava RK: Green tea polyphenols: biology and therapeutic implications in cancer. Frontiers in Biosciences 2007, 12:4881-4899.

12. Ramos S: Effects of dietary flavonoids on apoptotic pathways related to cancer chemoprevention. Journal of Nutritional Biochemistry 2007, 18:427-442.

13. Khan N, Mukhtar H: Multitargeted therapy of cancer by green tea polyphenols. Cancer Letters 2008, 269:269-280.

14. Zhao J, Wang J, Chen Y, et al: Anti-tumor-promoting activity of a polyphenolic fraction isolated from grape seeds in the mouse skin twostage initiation-promotion protocol and identification of procyanidin B53 '-gallate as the most effective antioxidant constituent. Carcinogenesis 1999, 20:1737-1745.

15. James R, Warburton S: Hemocytometer Cell Counts and Viability Studies: Cell Quantification. In Cell and Tissue Culture: Laboratory Procedures in Biotechnology. 1 edition. Edited by: Doyle A, Grifith JB. England: John Wiley 1999:57-61.

16. Wang W, Sun W, Wang X: Intramuscular gene transfer of CGRP inhibits neointimal hyperplasia after balloon injury in the rat abdominal aorta. American Journal of Physiology and Heart Circulation Physiolosy 2004, 287: H1582-H1589.

17. Shafi G, Munshi A, Hasan TN, Alshatwi AA, Jyothy A, Lei DKY: Induction of apoptosis in HeLa cells by chloroform fraction of seed extracts of Nigella sativa. Cancer Cell International 2009, 9:29.

18. Yuan JS, Reed A, Chen F, Stewart CN Jr: Statistical analysis of real-time PCR data. BMC Bioinformatics 2006, 7:85.

19. Motomura M, Kwon KM, Suh SJ, Lee YC, Kim YK, Lee IS, et al: Propolis induces cell cycle arrest and apoptosis in human leukemic U937 cells through $\mathrm{Bcl}-2 / \mathrm{Bax}$ regulation. Environmental Toxicology and Pharmacology 2008, 26:61-67.

20. Sen S, D'Incalci M: Biochemical events and relevance to cancer chemotherapy. FEBS Letters 1992, 307:122-127.

21. Khan MR, Mlungwana SM: c-sitosterol, a cytotoxic sterol from Markhamia zanzibarica and Kigelia africana. Fitoterapia 1999, 70:96-97.

22. Panchal RG: Novel therapeutic strategies to selectively kill cancer cells. Biochemical Pharmacology 1998, 55:247-252.

23. Farabegoli F, Papi A, Bartolini G, Ostan R, Orlandi M: (-)-Epigallocatechin3-gallatedownregulatesPg-PandBCRPinatamoxifen resistant MCF7celline. Phytomedicine 2010, 17:356-362.

24. Ahmeda K, Weia Z, Zhaoa Q, Nakajimab N, Matsunagac T, Ogasawarac M, Kondoa T: Role of fatty acid chain length on the induction of apoptosis by newly synthesized catechin derivatives. Chemico-Biological Interactions 2010, 185:182-188. 
25. Babich $H$, Krupka ME, Nissim HA, Zuckerbraun HL: Differential in vitro cytotoxicity of (-)-epicatechin gallate (ECG) to cancer and normal cells from the human oral cavity. Toxicology in vitro 2005, 19:231-242.

26. Hengartner MO: The biochemistry of apoptosis. Nature 2002, 407:770-776.

27. Shah S, Gapor A, Sylvester PW: Role of caspase-8 activation in mediating vitamin E-induced apoptosis in murine mammary cancer cells. Nutrition and Cancer 2003, 45:236-246.

28. Earnshaw WC, Martins LM, Kaufmann SH: Mammalian caspases Structure, activation, substrates, and functions during apoptosis. Annual Review of Biochemistry 1999, 68:383-424.

29. Riedl SJ, Shi Y: Molecular mechanisms of caspase regulation during apoptosis. Nature Review:Molecular Cell Biology 2004, 5:897-907.

30. Pommier Y, Sordet O, Antony S, Haywrd RL, Kohn KW: Apoptosis defects and chemotherapy resistance: molecular interaction maps and networks. Oncogene 2004, 23:2934-2949.

31. Malik F, Kumar A, Bhushan S, Khan S, Bhatia A, Suri KA, Qazi GN, Singh J: Reactive oxygen species generation and mitochondrial dysfunction in the apoptoticcell death of human myeloid leukemia $\mathrm{HL}-60$ cells by a dietary compoundwithaferin A with concomitant protection by $\mathrm{N}$-acetylcysteine. Apoptosis 2008, 12:2115-2133.

32. Johnstone RW, Ruefli AA, Lowe SW: Apoptosis: A link between cancer genetics and chemotherapy. Cell 2000, 108:153-164.

33. Fridman JS, Lowe SW: Control of apoptosis by p53. Oncogene 2003, 22:9030-9040.

34. Michalak E, Villunger A, Erlacher M, Strasser A: Death squads enlisted by the tumor suppressor p53. Biochemical and Biophysical Research Communications 2005, 331:786-798.

35. Takaoka A, Hayakawa S, Yanai H, Stoiber D, Negishi H, Kikuchi H, Sasaki S, Imai K, et al: Integration of interferon-alpha/beta signalling to $\mathrm{p} 53$ responses in tumour suppression and antiviral defence. Nature 2003, 424:516-23.

36. Pekar O, Molotski N, Savion S, Fein A, Toder V, Torchinsky A: $p 53$ regulates cyclophosphamide teratogenesis by controlling caspases $3,8,9$ activation and NF-KB DNA binding. Reproduction 2007, 134:379-388.

doi:10.1186/1756-9966-29-167

Cite this article as: Alshatwi: Catechin hydrate suppresses MCF-7 proliferation through TP53/Caspase-mediated apoptosis. Journal of Experimental \& Clinical Cancer Research 2010 29:167.

\section{Submit your next manuscript to BioMed Central and take full advantage of:}

- Convenient online submission

- Thorough peer review

- No space constraints or color figure charges

- Immediate publication on acceptance

- Inclusion in PubMed, CAS, Scopus and Google Scholar

- Research which is freely available for redistribution

Submit your manuscript at www.biomedcentral.com/submit 